\title{
Characteristics of motorcyclists involved in accidents between motorcycles and automobiles
}

\author{
Amanda Lima de Oliveira ${ }^{1}$, Andy Petroianu2*, Dafne Maria Villar Gonçalves ${ }^{3}$, Gisele Araújo Pereira ${ }^{3}$, Luiz Ronaldo Alberti ${ }^{4}$ \\ ${ }^{1}$ Medical student at the Federal University of Minas Gerais (UFMG) School of Medicine, Belo Horizonte, MG, Brazil. Grant holder with scientific production at the CNPq \\ ${ }^{2}$ Full Professor at the Surgery Department, Faculty of Medicine, UFMG, Post-doctoral Professor of Surgical Technique and Experimental Surgery, School of Medicine, Unifesp, Post-doctoral Professor of Surgical \\ Gastroenterology, School of Medicine of Ribeirão Preto, USP, PhD in Physiology and Pharmacology from the Institute of Biological Sciences, UFMG, CNPq Researcher 1B \\ ${ }^{3}$ Medical student at the UFMG School of Medicine, Grant holder with scientific production at the CNPq \\ "Adjunct Professor at the Department of Surgery, School of Medicine, UFMG, CNPq Researcher 2
}

Study conducted at Faculty of Medicine, Federal University of Minas Gerais

Article received: 6/12/2014 Accepted for publication: 6/15/2014

*Correspondence: Address: Avenida Afonso Pena, 1626 - apt. 1901 Postal code: 30130-005 Belo Horizonte, MG - Brazil petroian@gmail.com

Financial support: CNPq and FAPEMIG http://dx.doi.org/10.1590/1806-9282.61.01.061 Conflict of interest: none

\section{SUMMARY}

Introduction: traffic accidents are one of the main causes of death and disability, with motorcyclists representing the great majority of both the victims and the perpetrators.

Objective: this work studied the characteristics of motorcyclists injured in accidents involving motorcycles and automobiles.

Method: this study sought to interview 100 motorcyclists who had been injured in collisions between motorcycles and automobiles, and who were undergoing emergency hospital treatment in the region of Belo Horizonte, Brazil. The questionnaires included demographic information (age, gender, skin color, education level, profession) and questions about years of licensed driving practice, how often they would drive an automobile, how long they had had a motorcycle driver's license, how often they would ride a motorcycle, the number of prior accidents involving a car, and the number of prior accidents not involving a car.

Results: of the 100 consecutive accidents studied, 91 occurred with men and 9 with women, aged between 16 and $79(\mathrm{~m}=29 \pm 11)$ years. Regarding their reason for using a motorcycle, $83 \%$ reported using it for transport, $7 \%$ for work, and $10 \%$ for leisure. Most of these accident victims had secondary or higher education (47\%). Of the motorcyclists who held a car driver's license, $68.3 \%$ drove the vehicle daily or weekly and held the license for more than one year. Sixty-seven percent of the accident victims used a motorcycle daily and had a motorcycle driver's license for at least one year. Conclusion: among the motorcyclists injured, most were men aged 20 years or older, with complete secondary education, and experienced in driving both motorcycles and cars, indicating that recklessness while driving the motorcycle is the main cause of traffic accidents.

Keywords: motorcycle, automobile, accident, traffic, motorcyclist.

\section{INTRODUCTION}

Traffic accidents are a major cause of death and disability. In Brazil, over 980,000 people died due to traffic accidents in the period 1980-2011. ${ }^{1}$ According to World Health Organization data, these accidents are the number one cause of deaths in the age group between 15 and 29 years, and the third cause in the age range from 30 to 44 years. ${ }^{1}$

Data relating to the municipality of Belo Horizonte indicate that motorcyclists are the main non-fatal accident victims and represented $44.2 \%$ of the total number of injured in $2011 .^{2}$ In the same year, 8,884 motorcyclists were in traffic accidents in this municipality. ${ }^{2}$ From 1996 to 2011, the number of deaths of motorcyclists in Brazil increased $932.1 \%$. During this period, pedestrian deaths fell by $52.1 \%$, while the deaths of car occupants increased $72.9 \% .{ }^{1}$ Motorcyclists are involved in most of the traffic accidents. This fact results in increased public spending on treatment and rehabilitation of accident victims. In 2011 alone, there was a 44.6 billion reais loss with traffic accidents across the country. ${ }^{1}$

The steady increase in vehicle fleet contributes to a greater number of accidents. ${ }^{3}$ In Belo Horizonte, the number of motorcycles grew $114.7 \%$ from 2005 to 2011 and 
the number of accidents involving motorcyclists increased $46.7 \%$ in the same period. ${ }^{2}$ These numbers are alarming and lead to studies on the relationship between motorcycles and traffic accidents. This work studied the characteristics of motorcyclists injured in accidents involving motorcycles and automobiles.

\section{Methods}

The study included 100 motorcyclists involved in collisions between motorcycles and cars, which were being treated in emergency hospitals in the region of Belo Horizonte. The participation of motorcyclists in this study was voluntary and they signed a free and informed consent, after approval of the study project by the Ethics Committee of UFMG. (CAAE18741614.0.0000.5149). They all completed a questionnaire containing demographics (age, gender, skin color, education level, profession) and questions about years of licensed driving practice, how often they would drive a car, how long they had had a motorcycle driver's license, how often they would ride a motorcycle, the number of prior accidents involving a car, and the number of prior accidents not involving a car.

Education level was considered as incomplete primary education, complete primary education, complete secondary education, or complete post-secondary education. Occupation was divided into three groups, according to the purpose of motorcycle use: for work, transport or leisure. The frequency of use of the motorcycle was divided into daily, weekly and occasional.

Motorcyclists were asked if they had a license to drive motorcycles and/or cars. The time of licensed driving practice was counted in years. The authors considered as motorcycle accidents involving a car: collisions between car and motorcycle, and falls caused by cars, even without collision. Motorcycle accidents that did not involve cars were also assessed, including collisions with stationary objects, isolated falls and pedestrians being run over.

The sample size was based on the standard sample size calculation using the formula: $n=z^{2}(1-\alpha / 2) / 4 d^{2}$, considering $\alpha=0.05$. According to this calculation, the minimum reliable sample size is 96 individuals. Continuous data were presented as mean and standard deviation. The qualitative data were distributed by frequency. To compare categorical variables, we used chi-square test and Fisher's exact test. To compare continuous variables, we used the Student's t test for unpaired samples. Differences were considered significant at $\mathrm{p}<0.05$.

\section{Results}

Of the 100 consecutive accidents studied, 91 occurred with men and 9 with women, aged between 16 and 79 $(\mathrm{m}=29 \pm 11)$ years. With regard to skin color, $50 \%$ of patients were pheodermic (mulattos), 35\% were leukodermic (white) and $15 \%$ were melanodermic (black).

Regarding their reason for using a motorcycle, 83\% reported using it for transport, $7 \%$ for work, and $10 \%$ for leisure. Most of these accident victims had secondary or higher education (52\%).

Of the 100 motorcyclists surveyed, $7 \%$ had a license to drive cars only, $31 \%$ had a license to drive motorcycles only, and $47 \%$ had a license for both types of vehicles. Tables 1 and 2 show the distribution of injured motorcyclists according to the number of years of licensed driving practice, and the frequency of car and motorcycle use. Of the motorcyclists who held a car driver's license, $68.3 \%$ drove the vehicle daily or weekly and had their licenses for more than one year.

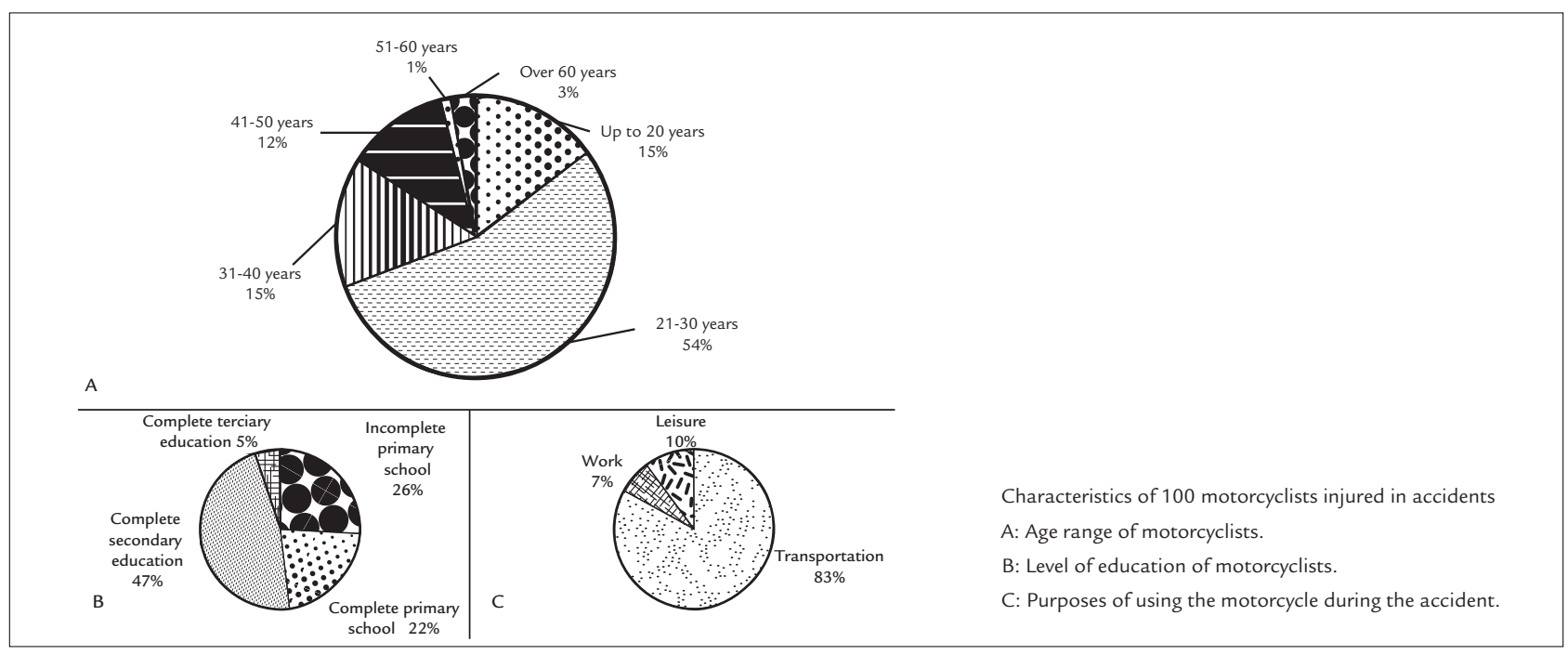

FIGURE 1 Age range and level of education of 100 motorcyclists involved in accidents while driving a motorcycle, who were in previous accidents with and without a car. 
TABLE 1 Car and motorcycle driving licenses of 100

motorcyclists who were involved in accidents, and how often they would drive either a motorcycle (M) or car (C)

\begin{tabular}{|c|c|c|c|c|c|c|c|c|c|}
\hline \multirow{3}{*}{\multicolumn{2}{|c|}{$\begin{array}{l}\text { Years of } \\
\text { licensed driving }\end{array}$}} & \multicolumn{8}{|c|}{ Frequency of driving } \\
\hline & & \multicolumn{2}{|c|}{ Daily } & \multicolumn{2}{|c|}{ Weekly } & \multicolumn{2}{|c|}{ Occasional } & \multicolumn{2}{|c|}{ Total } \\
\hline & & C & $\mathbf{M}$ & C & $\mathbf{M}$ & C & M & C & $\mathbf{M}$ \\
\hline \multirow{2}{*}{$\begin{array}{l}\text { Did not } \\
\text { have a } \\
\text { license }\end{array}$} & C & 1 & & 3 & & 4 & & 8 & \\
\hline & $\mathbf{M}$ & & 10 & & 5 & & 7 & & 22 \\
\hline \multirow[t]{2}{*}{$<1$ year } & $\mathrm{C}$ & 1 & & 3 & & 1 & & 5 & \\
\hline & $\mathbf{M}$ & & 5 & & 0 & & 0 & & 5 \\
\hline \multirow[t]{2}{*}{1 to 5 years } & $\mathrm{C}$ & 10 & & 11 & & 1 & & 22 & \\
\hline & $\mathbf{M}$ & & 45 & & 2 & & 2 & & 49 \\
\hline \multirow[t]{2}{*}{$>5$ years } & $\mathrm{C}$ & 11 & & 9 & & 5 & & 25 & \\
\hline & $\mathbf{M}$ & & 22 & & 1 & & 1 & & 24 \\
\hline \multirow[t]{2}{*}{ Total } & $\mathrm{C}$ & 23 & & 26 & & 11 & & 60 & \\
\hline & $\mathbf{M}$ & & 82 & & 8 & & 10 & & 100 \\
\hline
\end{tabular}

Among the injured who drove a motorcycle, $67 \%$ used the vehicle daily and had their motorcycle driving licenses for at least one year $(p=0.001)$. Table 2 shows the distribution of previous accidents according to age and educational level of motorcyclists. Of the 100 motorcyclists surveyed, 48 had been involved in accidents before while driving a motorcycle. Most of them had finished high school and were aged between 20 and 40 years. Of the 48 motorcyclists who reported previous accidents, $50 \%$ only had accidents that did not involve cars, $27.1 \%$ had car accidents, and $22.9 \%$ were involved in accidents with and without cars.

\section{Discussion}

According to official data, there are more male than female motorcyclists $(90.37 \%)$. Yet, the incidence of injured men $(91 \%)$ in this study is a worrying statistic in terms of how prepared they are to drive a motorcycle. The prevalence of this group in research on traffic accidents is a common result. ${ }^{4,5}$ It is noticed that accidents were not due to lack of knowledge of traffic laws, given that most were older than 20 years with a high school diploma and a motorcycle driver's license for longer than one year.

It is expected that adolescents could endanger their physical integrity in the search for limits and need for self-assertion. ${ }^{6}$ Based on this premise, younger motorcyclists and during the first months after acquiring their licenses to drive a motorcycle should have been the most involved in these accidents. However, the injured were mostly adults who apparently no longer had to prove themselves as motorcyclists and were aware of the risks in motorcycle driving. In addition, half of them had been involved in previous accidents.

Another possibility would be collision with car because the motorcyclist does not know how car drivers are supposed to drive their vehicles. However, more than half of the injured motorcyclists also had a license to drive cars and did it at least weekly, indicating therefore that accidents were not due to lack of knowledge on how to drive a car. Note that none of these motorcyclists had had a serious accident while driving a car.

It is also worth mentioning the results of a previous study, in which we found that almost all of those run over by cars in the streets of Belo Horizonte were people without a driver's license. ${ }^{7}$ In this sense, there was the assumption that motorcyclists would also have this characteristic. However, this was not the case in this work.

Most of the motorcyclists injured were in traffic daily, and used their motorcycles for transportation, thus indicating that they understood and were used to the risks of traffic. On the other hand, motorcyclists driving their motorcycles for work purposes were only $7 \%$ indicating they are more cautious than the others. In traffic, many motorcyclists at work seem to drive their motorcycles recklessly; however, this research reveals that they remain within the limit of safe, probably because that is how they make a living. Motorcyclists who drove their motorcycles for pleasure had fewer accidents, probably because they did not hurry and were less reckless.

TABLE 2 Age range and level of education of 100 motorcyclists involved in accidents while driving a motorcycle, who were in previous accidents with and without a car

\begin{tabular}{|c|c|c|c|c|}
\hline \multirow[t]{2}{*}{ Parameters } & \multicolumn{4}{|c|}{ Previous accidents } \\
\hline & With a car & Without a car & With and without a car & Total \\
\hline \multicolumn{5}{|l|}{ Age } \\
\hline$<20$ years & 1 & 2 & 1 & 4 \\
\hline 20 to 40 years & 11 & 16 & 8 & 35 \\
\hline$>40$ years & 1 & 6 & 2 & 9 \\
\hline Total & 13 & 24 & 11 & 48 \\
\hline \multicolumn{5}{|l|}{ Level of education } \\
\hline$\leq$ Complete primary education & 4 & 11 & 7 & 22 \\
\hline Complete secondary education & 9 & 13 & 4 & 26 \\
\hline Post-secondary education & 0 & 0 & 0 & 0 \\
\hline Total & 13 & 24 & 11 & 48 \\
\hline
\end{tabular}


Some blame the car drivers for the accidents, since they are in safer conditions compared to motorcyclists, and may be more aggressive in traffic. ${ }^{8,9}$ Still, one should consider that in most traffic accidents, regardless of the type of vehicle, both drivers are guilty, even if in different degrees. If at least one of the drivers is prudent and obeys the traffic laws, it is unlikely that an accident occurs.

Considering that half of the accidents occurred with motorcyclists who used the motorcycle for transportation, it is pertinent to assume they exceeded the safety limits while driving their vehicles. ${ }^{10-12}$ In general, people choose to use a motorcycle because they are faster, traveling between lanes and overtaking slow vehicles more easily. The desire or the need to reduce the time to get to a particular location certainly motivates the recklessness of experienced motorcyclists. It is possible that these motorcyclists have become less careful after previous minor transgressions that did not have adverse consequences. Car drivers may be blamed in part for the accidents, but these events would not have occurred if the motorcyclists had followed the traffic laws, which are all known to them.

In conclusion, these data indicate that accidents involving motorcycles are the result of the carelessness of some motorcyclists. To reinforce this situation, it became clear that accidents with female motorcyclists, who drive more carefully and respect traffic laws, are rare. Men who drive their motorcycles exceeding the safety limit, in turn, are not able to dodge the accident when it is caused by some unexpected fact in traffic.

\section{Acknowledgements}

The authors thank the CNPq (National Council of Scientific and Technological Development) and FAPEMIG (Minas Gerais State Research Foundation) for the financial support to this research.

\section{Resumo}

Características dos motociclistas envolvidos em acidentes entre motocicleta e automóvel.

Introdução: os acidentes de trânsito são uma das principais causas de morte e invalidez, sendo os motociclistas a maior parte de suas vítimas e seus causadores.

Objetivo: estudar as características dos motociclistas envolvidos em acidentes entre motocicletas e automóveis.

Métodos: foram entrevistados 100 motociclistas feridos em colisões entre motocicleta e automóvel que se encontravam em tratamento hospitalar de urgência no município de Belo Horizonte. O questionário continha sua identificação (idade, sexo, cor da pele, escolaridade, profissão) e perguntas sobre tempo de habilitação para dirigirem automóvel, frequência com que dirigiam automóvel, tempo de habilitação para conduzirem motocicleta, frequência com que dirigiam motocicleta, número de acidentes prévios envolvendo automóvel e número de acidentes prévios sem relação com automóvel.

Resultados: dos 100 acidentados consecutivos estudados, 91 eram homens e 9 eram mulheres com idade de 16 a 79 anos $(M=29 \pm 11)$. Quanto à finalidade do uso da motocicleta, $83 \%$ a empregavam para transporte, $7 \%$ para trabalho e $10 \%$ para lazer, tendo a maior parte dos acidentados pelo menos o ensino médio completo (47\%). Dos motociclistas que possuíam habilitação para automóvel, $68,3 \%$ dirigiam o veículo diária ou semanalmente e possuíam a habilitação por período superior a 1 ano; $67 \%$ dos acidentados conduziam motocicleta diariamente e tinham pelo menos 1 ano de habilitação para motocicleta.

Conclusão: entre os 100 acidentados, predominaram homens com idade superior a 20 anos, ensino médio completo, experiência em conduzir motocicletas e automóveis, indicando que a imprudência ao conduzir a motocicleta tenha sido a principal causa de acidentes de trânsito.

Palavras-chave: motocicleta, automóvel, acidente, trânsito, motociclista.

\section{References}

1. Waiselfisz, JJ. Mapa da violência 2013: acidentes de trânsito e motocicletas, 2013.

2. Empresa de transportes e trânsito de Belo Horizonte S/A-BHTRANS. Informações sobre acidentes de trânsito com vítimas no município de Belo Horizonte, 2011.

3. Koizumi, MS. Acidentes de motocicleta no município de São Paulo. Rev Saúde Pública. 1985; 19:475-89.

4. Gawryszewski VP, Coelho HMM, Scarpelini SZR, Jorge MHPM, Rodrigues SEM. Perfil dos atendimentos a acidentes de transporte terrestre por serviços de emergência em São Paulo, 2005. Rev Saúde Pública. 2009; 43:275-82.

5. Santos AMR, Moura MEB, Nunes BMVT, Leal CFS, Teles JBM. Perfil das vítimas de trauma por acidente de moto atendidas em um serviço público de emergência. Cadernos Saúde Pública. 2008; 24:1927-38.

6. Bjornskau T, Naevestad TO, Akhtar J. Traffic safety among motorcyclists in Norway: A study of subgroups and risk factors. Accident Analysis Prevention. 2012; 49:50.

7. Fagundes PWJ, Tanure R, Petroianu A. Conhecimento das leis de trânsito por vítimas de atropelamento, em Belo Horizonte, em 1997. Medicina. 1999; 32:189-92

8. Pai CW. Motorcycle right-of-way accidents - A literature review. Accident Analysis Prevention. 2011; 43:971-82.

9. Magazzù $\mathrm{D}$, Comelli $\mathrm{M}$, Marinoni A. Are car drivers holding a motorcycle license less responsible for motorcycle-car crash occurrence? National Library of Medicine. 2006; 38:365-70.

10. Cheng ASK, Ng TCK, Lee HC. A comparison of the hazard perception ability of accident-involved and accident-free motorcycle riders. Accident Analysis Prevention. 2011; 43:1464-71.

11. Cheng AS, Ng TC. Development of a Chinese motorcycle rider driving violation questionnaire. Accident analysis and prevention. 2010; 42:1250-6.

12. Lin MR, Chang SH, Pai L, Keyl PM. A longitudinal study of risk factors for motorcycle crashes among junior college students in Taiwan. Accident Analysis Prevention. 2003; 35:243-52. 